Karstenia 50: 59-72, 2010

\title{
Ascomycetes and anamorphic fungi growing on Plagiochila (Hepaticae) in Finland
}

\author{
TARJA MARSH, PETER DÖBBELER, SEPPO HUHTINEN and SOILI STENROOS
}

\begin{abstract}
MARSH, T., DÖBBELER, P., HUHTINEN, S. \& STENROOS, S. 2010: Ascomycetes and anamorphic fungi growing on Plagiochila (Hepaticae) in Finland. - Karstenia 50: 59-72. Helsinki. ISSN 0453-3402.

Over 400 Finnish herbarium specimens of the hepatics Plagiochila asplenioides and the closely related $P$. porelloides were screened for the presence of fungi. The screening yielded ca. 200 recordings of bryicolous species belonging to the ascomycete genera Bryomyces, Dactylospora, Epibryon, Lichenopeltella, Octosporella, Pleostigma, and the anamorphic genus Epicoccum. With the exception of Epibryon plagiochilae, the species are new to Finland. They are described and illustrated. Their morphology, taxonomy and ecology are discussed and their distribution in Finland is mapped. A key is given to all known bryicolous fungi found on P. asplenioides (incl. P. porelloides).
\end{abstract}

Keywords: Ascomycetes, bryicolous fungi, hepaticolous fungi, Plagiochila asplenioides, P. porelloides

Tarja Marsh \& Seppo Huhtinen, Herbarium, University of Turku, FI-20014 Turku, Finland; e-mails:tarja.marsh@utu.fi \& seppo.huhtinen@utu.fi

Peter Döbbeler, Ludwig-Maximilians-Universität München, Fakultät für Biologie, Systematische Botanik und Mykologie, Menzinger Strasse 67, D-80638 München, Germany; e-mail:doebbeler@lrz.uni-muenchen.de

Soili Stenroos, Botanical Museum, Finnish Museum of Natural History, P.O. Box 7, FI-00014 University of Helsinki, Finland; e-mail: soili.stenroos@helsinki.fi

\section{Introduction}

The presence of fungi on bryophytes may be more apparent to bryologists than mycologists, as mosses and hepatics host a wide range of fungi, some of which are common and easily visible under the stereo microscope. However, perhaps due to the lack of communication between researches of these different fields bryicolous fungi have been seriously overlooked. The first account of pyrenomycetes and fungi imperfecti occuring on the gametophytes and sporophytes of mosses and hepatics was presented by Racovitza (1959). Döbbeler (1978) continued the work by describing and keying 62 new and 61 previously known species of ascomycetes mainly on the haploid stage of bryophytes. A brief literature review of the gametophyte-inhabiting fungi has been compiled by Felix (1988).

Up to date, the total number of bryicolous ascomycetes described is ca. 350 species (Döbbeler 2002). They belong to more than 90 genera and at least ten orders, including Arthoniales, Dothideales, Helotiales, Hypocreales, Lecanorales, Microthyriales, Ostropales, Pezizales, Sordariales, and Verrucariales, some taxa remaining incertae sedis. Bryicolous fungi are by no means chance companions of their partners: there are several obligately bryicolous ascomycete genera which suggests that the relationship between the fungus and its host may have an ancient origin. Davey \& Currah (2006) have provided a litera- 
ture review of interactions between mosses and fungi. These interactions range from pathogenic to commensalistic, biotrophic parasitism by the fungus-partner probably being the most common (Döbbeler 2002).

A bryicolous lifestyle requires several morphological and physiological adaptations of the fungus, including the minute size of the fruit bodies, the ability to produce them all year round, specialized infection structures of the hyphae, and adaptations for reducing water-loss. The fruit bodies are not formed randomly on the host, but at species-specific microsites, reflecting the ecology of the fungus. Thorough summaries on the diversity and microniche utilization of bryicolous ascomycetes can be found in Döbbeler $(1997,2002)$.

Presently, about 300-400 species of mosses and hepatics have been proved to host bryicolous ascomycetes (Felix 1988). Just a handful of bryophyte species have been screened systematically for microfungi (e.g., Döbbeler 1981b, 1998, 2003, 2006, 2007, Laukka 2005, Lesonen 2006, Marsh 2005). These numbers constitute only the tiniest fraction of potential hosts, 18000 estimated species of mosses and hepatics (Schofield 1985), that are all likely to harbor fungal associates.
The host species Plagiochila asplenioides and P. porelloides

The hepatic genus Plagiochila (Dumort.) Dumort. is one of the largest genera of hepatics, with an estimated number of 400-450 species (So \& Grolle 2000) and over 2500 taxa published (Inoue 1989). Members of the genus occur worldwide, but the species diversity is greatest in the humid tropics, where Plagiochila is one of the most common bryophytes (Inoue 1984). Plagiochila is characterized by general robustness and alternate, succubously inserted, often decurrent leaves (Damsholt 2002).

In Finland the only representatives of the genus are $P$. asplenioides (L.) Dumort. and $P$. porelloides (Torrey ex Nees) Lindenb. Species restrictions within the $P$. asplenioides -complex have been discussed controversially. Schuster (1980) and Damsholt (2002) regarded P. porelloides as a subspecies of $P$. asplenioides, whereas Paton (1999) and Schumacker \& Váňa (2000) accepted two species. Both taxa are common and abundant in Finland. P. asplenioides prefers herb-rich forest floors and moist depressions. $P$. porelloides can be found on bases and crevices of shady silicate boulders, sometimes by brooks or on dead wood in shady forests.

Table 1. Ascomycetes previously recorded on Plagiochila asplenioides s.l.

\begin{tabular}{|l|l|}
\hline Name & Reference \\
\hline Belonioscyphella hypnorum (Syd. \& P. Syd.) Höhn. & Döbbeler 1986a \\
\hline Bryomyces hemisphaericus Döbbeler & Döbbeler 1978 \\
\hline Bryorella erumpens Döbbeler & Döbbeler 1978 \\
\hline Dactylospora heimerlii (Zukal) Döbbeler \& Triebel & Döbbeler \& Triebel 1985 \\
\hline Epibryon endocarpum Döbbeler & Döbbeler 1980a \\
\hline Epibryon muscicola (Racov.) Döbbeler & $\begin{array}{l}\text { Racovitza 1959, } \\
\text { Döbbeler 1978 }\end{array}$ \\
\hline Epibryon plagiochilae (Gonz. Frag.) Döbbeler & $\begin{array}{l}\text { Racovitza 1959, } \\
\text { Döbbeler 1978 }\end{array}$ \\
\hline Epicoccum plagiochilae Racov. & $\begin{array}{l}\text { Racovitza 1959, } \\
\text { Döbbeler 1986b }\end{array}$ \\
\hline Nectria racovitzae Döbbeler & Döbbeler 1978 \\
\hline Nectria salisburgensis Döbbeler \& Poelt & Döbbeler 1978 \\
\hline Octosporella jungermanniarum (P. Crouan \& H. Crouan) Döbbeler & $\begin{array}{l}\text { Corner 1929, } \\
\text { Döbbeler 1978 }\end{array}$ \\
\hline Phoma plagiochilae Racov. & $\begin{array}{l}\text { Racovitza 1959, } \\
\text { Döbbeler 1981a }\end{array}$ \\
\hline Pleostigma jungermanniicola (C. Massal.) Kirschst. & Racovitza 1959 \\
\hline
\end{tabular}


Thirteen species of bryicolous fungi have previously been recorded in association with $P$. asplenioides and/or $P$. porelloides (Table 1). It has not always come clear, especially from older literature, which of the two Plagiochila -species has been in question, therefore all associated species referred from literature have been grouped collectively under P. asplenioides s.1.

\section{Material and methods}

The study is based mainly on dry herbarium material from the bryological collections of the Botanical Museums of Turku (TUR) and Oulu (OULU). The laboratory work was carried out during the year 2004. The search for fruit bodies requires wetting the herbarium specimens of Plagiochila thoroughly under flowing tap water. Rehydration of the material restores the size of the ascomata, facilitates the handling of the hepatic, which is fragile and brittle when dry and removes some of the debris from the gametopyte. Each specimen of Plagiochila was subsequently screened, one shoot at a time, under an Olympus SZX9 stereo microscope, both from the dorsal and ventral sides of the leaves and around the stem. The handling of the hepatic was done with utmost care, so that it could be returned to the herbarium in good condition. The search for ascomata is facilitated by the knowledge of their species-specific microniches on the host (Döbbeler 2002). Shoots containing ascomata were separated from the original specimen for further investigation.

Morphological structures of the ascomata were studied using squash mounts. The mounts were observed with an Olympus BX40 light microscope. Spores, asci, paraphyses or pseudoparaphyses, wall structure, hairs or other features of the ascoma were observed and measured. Growth pattern of mycelia was observed from leaf preparates. A drawing tubus, attached to the microscope, was used to make illustrations of the structures. Congo Red (CR) was used as standard staining liquid to make structures more clearly visible. Iodine reactions were tested with Melzer's Reagent (MLZ) and Lugol's solution (IKI). Cotton blue (CB) was used to stain the hyphae in leaf preparates. All measurements originate from rehydrated herbarium material stained with Congo Red.

The genera in which the collected ascomycete species are positioned are presented shortly, followed by species descriptions, distribution map in Finland, and comments. Species descriptions one to eight are of those species, which were encountered during this study (Table 2), and their descriptions are based on personal observations and measurements. The descriptions of the rest of the species are abbreviated from relevant literature. The latter have been reported from Plagiochila, but have not yet been recorded from Finland. The maps provided present a picture of collections in the past and present, rather than reflect the true distribution of the species.

\section{Results}

About half of the Plagiochila -specimens examined hosted bryicolous ascomycetes belonging to eight different species (Table 2). Only Epibryon plagiochilae (Gonz. Frag.) Döbbeler was previously known from Finland. Bryomyces hemisphaericus Döbbeler, Dactylospora heimerlii (Zukal) Döbbeler \& Triebel, Epicoccum plagiochilae Racov., Lichenopeltella alpestris (Sacc.) P.M. Kirk \& Minter, Octosporella jungermanniarum (P. Crouan \& H. Crouan) Döbbeler, and Pleostigma jungermanniicola (C. Massal.) Kirschst. are reported as new to Finland. One previously undescribed species of Epibryon is characterized.

Table 2. Ascomycetes found in this study and number of infected specimens

\begin{tabular}{|l|c|c|}
\hline & $\begin{array}{c}\text { P. asplenioides } \\
\text { / ca. 200 studied }\end{array}$ & $\begin{array}{c}\text { P. porelloides } \\
\text { / ca. 200 studied }\end{array}$ \\
\hline Bryomyces hemisphaericus & - & 2 \\
\hline Dactylospora heimerlii & - & 6 \\
\hline Epibryon plagiochilae & 97 & 8 \\
\hline Epibryon sp. & - & 6 \\
\hline Epicoccum plagiochilae & 1 & 2 \\
\hline Lichenopeltella alpestris & 35 & 6 \\
\hline Octosporella jungermanniarum & 5 & 1 \\
\hline Pleostigma jungermanniicola & 8 & 22 \\
\hline
\end{tabular}


Key to all species recorded on Plagiochila asplenioides s.1.

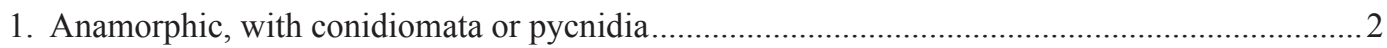

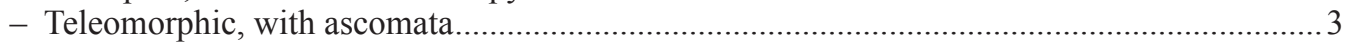

2. Conidiomata superficial, conidia two-celled, dark brown

5. Epicoccum plagiochilae

- Pycnidia within the leaf tissue, conidia one-celled, colourless.

15. Phoma plagiochilae

3. Ascomata catathecioid, excipular cells arranged in rows

- Ascomata not catathecioid

6. Lichenopeltella alpestris

4. Ascomata singly within individual host cells.

11. Epibryon endocarpum

- Ascomata not within individual host cells

5. Ascoma black, sphaerical, with hairs

- Not with this character combination

6. Spores four-celled

12. Epibryon muscicola

- Spores two-celled

7. Ascomata 50-100 $\mu \mathrm{m}$ diam, scattered on upper leaf surface, hairs horizontal or more often curved downward

3. Epibryon plagiochilae

- Ascomata 40-70 $\mu \mathrm{m}$ diam, growing in leaf axils, hairs horizontal or pointed upwards.

4. Epibryon sp.

8. Ascomata perithecioid, glabrous

- Ascomata either hairy and perithecioid or apothecioid and glabrous

9. Spores muriform

8. Pleostigma jungermanniicola

- Spores two-celled

10. Ascomata superficial, spores ca.13-16 $\times 6-7 \mu \mathrm{m}$.

1. Bryomyces hemisphaericus - Ascomata immersed, spores. ca. 9-11 × 3-3.5 $\mu \mathrm{m}$.

10. Bryorella erumpens

11. Ascomata perithecioid, hairy

- Ascomata apothecioid, without hairs

12. Spores without septa

7. Octosporella jungermanniarum

- Spores septate....

13. Spores $25-35 \times 6-7 \mu \mathrm{m}$

13. Nectria racovitzae - Spores $6.5-8.5 \times 1.5-2 \mu \mathrm{m}$ 14. Nectria salisburgensis

14. Apothecia brownish, with a distinct margin, spores $13-20 \times 5-8 \mu \mathrm{m}$, usually one-septate, biotrophic parasite

2. Dactylospora heimerlii - Apothecia reddish, disc flat, spores 33-40 × 7-8.5 $\mu \mathrm{m}$, usually three-septate, necrotrophic parasite

9. Belonioscyphella hypnorum 


\section{Bryomyces hemisphaericus - Fig. 5,8}

Ascomata 50-120 $\mu \mathrm{m}$ diam, superficial, often gregariously but not merging, semiglobose to rarely globose, black, glabrous. Ostiole 10-18 $\mu \mathrm{m}$ diam, circular, not easily visible. Excipulum composed from 3-5 layers of isodiametric, very thick-walled brownish cells. Asci $28-45 \times 17-22 \mu \mathrm{m}, 8$-spored, bitunicate, ovoid to slightly clavate, foot short or absent, MLZ-. Spores 13-16(-17) $\times(5-) 6-7 \mu \mathrm{m}$, ellipsoid, hyaline or light-brown, smooth-walled, two-celled, strongly constricted at the septum, upper half nearly semiglobose, each cell commonly containing one large or several small oil droplets, one or both cells with a $3 \mu \mathrm{m}$ long, hyaline appendage. Paraphyses absent. Hyphae brown, conspicuous, cells $4-10(-15) \times 3-6 \mu \mathrm{m}$, ellipsoid in cross-section, thick-walled. The hyphae follow the hosts cell walls superficially, occasionally pegging the hosts cell wall with haustoria. In the vicinity of the ascomata, the hyphae form dense, stroma-like cushions.

Specimens studied: FINLAND. Etelä-Häme. Ruovesi, Helvetinjärvi, on $P$. porelloides, 29.VI.1939 Söyrinki (TUR ). Tampere, Teisko, Männistö, on $P$. porelloides, 3.VIII.1967 Laine (TUR).

The genus Bryomyces Döbbeler contains 12 taxa found on hepatics and mosses. It is characterized by medium-sized, glabrous ascomata, absence of iodine reaction, and two-celled spores. Typical growth of mycelia and haustoria make it possible to identify the genus even when the ascomata are absent (Döbbeler 1978). While some of the species in this genus are reported to be widespread and fairly easy to identify, some of them may be quite difficult to distinguish (Döbbeler 2003). The ascomata of $B$. hemisphaericus were located in the lower part of infected plants, either on the dorsal side of the leaf or on the stem. The fruit body formation does not seem to be strictly localized; instead the fungus seems to colonize distinct areas of the plant with several ascomata forming in each other's vicinity. A heavy infection might even be visible in the field, since the leaves of the host plant may be covered in masses of black hyphae.

\section{Dactylospora heimerlii - Fig. 7, 9}

Apothecia rounded, 110-270(-400) $\mu \mathrm{m}$ diam, light brown to rarely black, urceolate to shortly stalked, concave when young, later disc even, with a distinct margin. Ectal excipulum composed of isodiametric, thick-walled cells, $13 \mu \mathrm{m}$ diam, often with a rounded lumen. Asci (42-)50 $80(-90) \times(10-) 11-15 \mu \mathrm{m}$, clavate, eight-spored (rarely 4-7 spores), thickened at the apex, IKI stains the outer wall blue, especially apically, $\mathrm{KOH}-$ pretreatment deepens the apical staining. Spores hyaline, rarely brownish when mature, $(12-) 13-20(-21) \times(4-) 5-8(-8.5) \mu \mathrm{m}$, ellipsoid to elongate-ellipsoid, usually slightly asymmetrically one-septate, rarely with 2-4 septa, smooth. Paraphyses branching. Hyphae hyaline, up to $1,5 \mu \mathrm{m}$ diam, ramifying, growing between host cells, especially in cell corners, and outer layer of stem.

Specimens studied: FINLAND. Varsinais-Suomi. Länsi-Turunmaa, Parainen, on P. porelloides, 20.VII.2004 Marsh (TUR). Uusimaa. Helsinki, Töölönpuisto, on $P$. porelloides, 24.X.1884 Lindberg (TUR). Sipoo, Pickala, on Jungermannia leiantha, 23.V.3009 Syrjänen, Niemi \& Savola (TUR). Etelä-Häme. Orivesi, Yliskylä, on P. porelloides, 6.VIII.1962 Laine (TUR). Ruovesi, Kukonpohja, on P. porelloides, 13.VI.1978 Söyrinki (TUR, OULU). Pohjois-Häme. Virrat, lowest lake of Toriseva, on P. porelloides, 22.VI.1948 Söyrinki (TUR, OULU). Oulun Pohjanmaa. Kiiminki, Isohalmeenmaa, on $P$. porelloides, 10.VII.1984 Väre (TUR).

Dactylospora Körb. is a widely distributed genus of ascomycetes with ca. 49 species (Kirk et al. 2008), most of which are lichenicolous but may also be found on hepatics, fungi, herbaceous plant material or dead wood. The morphological features of Dactylopora include asci with an amyloid, apical cap and a gelatinized, IKI+ outer layer (Hafellner 1979). Dactylospora heimerlii is reported as new to Finland. The apothecia found in this study were located mainly in the leaf axils or the perianths of $P$. porelloides. They occurred both in the healthy green parts and the decaying, lower parts of the stem. D. heimerlii has previously been recorded from nine hosts all belonging to different genera in the Jungermanniales (Döbbeler \& Triebel 1985), most of which occur in Finland.

\section{Epibryon plagiochilae - Fig. 2, 10}

Ascomata superficial, gregariously or dispersed, very rarely merged, 50-100 $\mu \mathrm{m}$ diam, semiglobose, usually with hairs, brown to black. Ostiole 7-13 $\mu \mathrm{m}$ diam, visible under the microscope as 
a clear circular spot. Hairs located in the upper third of the ascoma, usually sparse, horizontal, often bending towards the substratum, 20-55(-70) $\times 3-4 \mu \mathrm{m}$, dark-brown to blackish, one-celled, hairs may also be short or lacking. Excipulum composed of light-brown, thin-walled cells, ca. $6 \mu \mathrm{m}$ diam, cells surrounding the ostiole $2-4 \mu \mathrm{m}$ diam, isodiametric, thick-walled, brown. Asci (20-)24-40 × 7-12 $\mu \mathrm{m}$, eight-spored, bitunicate, from ellipsoid to cylindrical, foot short, hymenial gel red in IKI. Spores biseriate or irregularly biseriate, $(8.5-) 9-10(-16.5) \times 2.5-3(-4) \mu \mathrm{m}$, ellipsoid, smooth, two-celled, not constricted at the septum, lower cell slightly smaller, may have single guttules. Hyphae light-brown, cells 1-2 $\mu \mathrm{m}$ diam, thin-walled. The hyphae grow superficially on the anticlinal host cell walls, occasionally perforating some cells and filling them with mycelia which has short, 4-7 $\mu \mathrm{m}$ thick ovoid to ellipsoid cells. Hyphae may be seen abundantly in the vicinity of ascomata.

Selected specimens studied (all on P. asplenioides): FINLAND. Varsinais-Suomi. Karjalohja, Puujärvi, 24.IX.1979 Laine (TUR). Uusimaa. Espoo, Röylä, 7.X.1962 Isoviita (TUR). Etelä-Häme. Ruovesi, Hyytiälä, 21.VI.1943 Söyrinki (TUR, OULU). PohjoisHäme. Konginkangas, Pyyrinlahti, 10.X.1964 Isoviita (TUR). Kainuu. Sotkamo, Laaka, 24.IX.1996 Ulvinen (TUR, OULU).

The genus Epibryon Döbbeler accommodates ca. 45 species according to current knowledge and is the largest genus of bryicolous ascomycetes, with also a few lichenicolous representatives. However, it is not considered as a natural group, but rather a collection of species sufficiently similar in appearance to be placed in the same genus (Döbbeler 1997). The ascomata in this genus are globose or semiglobose, 30-120(-200) $\mu \mathrm{m}$ diam. Most species grow on the surface of their host, although some grow immersed in their substratum, intracellularly, or in some cases between the lamellae of Polytrichales. A typical feature of the genus is that the hymenial gel stains red in IKI. Epibryon species are widespread and common on a great variety of mosses and hepatics. They prefer hosts that belong to Jungermanniales and Polytrichaceae. Most representatives of the genus are biotrophic parasites, which rarely harm their host even though ascomata may sometimes be abundant.
Epibryon plagiochilae shows a strong preference for the dorsal leaf border of its host hepatic, although ascomata can also occur on the stem or on female bracts and perianths. The species has previously been thought to be specific to $P$. asplenioides and $P$. porelloides, occurrence on $P$. porelloides being significantly lower. However, there have been recent observations of E. plagiochilae also occurring on Plagiochila britannica (Bosanquet 2007). This observation would be in accordance with the cytological evidence that suggests that $P$. britannica has originated from P. asplenioides and P. porelloides via allopolyploidy (Newton 1986). In all, 105 specimens were found from the ca. 400 studied collections. The distribution follows that of the host hepatic. E. plagiochilae was recorded from the following regions: Ahvenanmaa, Varsinais-Suomi, Uusimaa, Satakunta, Etelä-Häme, Pohjois-Häme, Etelä-Savo, Etelä-Karjala, Pohjois-Savo, KeskiPohjanmaa, Oulun Pohjanmaa, and Kainuu.

\section{Epibryon sp. - Fig. 11}

An additional Epibryon species which was encountered during the research is briefly characterized here. As mentioned above, Epibryon species are among the most often encountered fungi on bryophytes. However, their species delimitation is challenging, and knowledge of their morphological variation and host selection is still limited. The material found was scarce, and the differences to other Epibryon species are minimal, therefore official species description shall be omitted.

Ascomata superficial, single, rarely merged, 40-70 $\mu \mathrm{m}$ diam, semiglobose, with hairs, brown to blackish. Ostiole circular, not easily visible. Hairs (15-)20-30 × 2-3 $\mu \mathrm{m}$, usually abundant, ca. $60-100$ on each perithecium, black to brown, single-celled. Excipulum composed of isodiametric, brown cells, 3.5-5 $\mu \mathrm{m}$ diam. Asci eightspored, cylindrical, curved, bitunicate. Spores irregularly in ascus, 9-13 $\times 3-5 \mu \mathrm{m}$, ellipsoid or slightly allantoid, hyaline, two-celled, constricted at septum.

Specimens studied (all on P. porelloides): FINLAND. Varsinais-Suomi. Länsi-Turunmaa, Parainen, Kirjala, 20.VII.2004 Marsh (TUR). Etelä-Häme. Ruovesi, Kukonpohja, 13.VI.1978 Söyrinki (TUR). Tampere, 20.VIII.1913 Helaakoski (TUR, OULU). Pohjois-Häme. Toivakka, Huikko, 30.X.1971 Ohenoja 25 (TUR, OULU). 
Pohjois-Savo. Rautalampi, Hoikankylä, 30.VIII.1982 Fagerstén 5128 (TUR, OULU). Kainuu. Paltamo, Mieslahti, 20.VI.1927 Metsävainio (TUR, OULU).

The species was placed in the genus Epibryon based on the bitunicate asci, hyaline, two-celled spores, and the general appearance of the ascoma. The iodine reaction was not analysed. The spores are somewhat constricted at the septum, while spores of $E$. plagiochilae are not. The most prominent differences are in the general habitus and the microhabitat. Epibryon sp. has more and shorter hairs than E. plagiochilae. Epibryon sp. is found in the leaf axils, whereas E. plagiochilae shows a strong preference for the dorsal edge of the leaf area never appearing in the axils.

\section{Epicoccum plagiochilae - Fig. 3, 12}

Conidioma superficial, 60-200(-250) $\mu \mathrm{m}$ diam, circular to oval, brown to blackish. Conidiophores unbranched. Conidia two-celled, 14$18(-19) \mu \mathrm{m}$, brown to blackish, upper cell globose, $10-14 \mu \mathrm{m}$, verrucose, the lower cell less verrucose. Hyphae superficial, (2.5-)3-4(-5) $\mu \mathrm{m}$ thick, dark brown, ramifying, partly following the anticlinal host cell walls, on both sides of the host leaf, sometimes even covering the stem. Appressoria ellipsoid, 7-13(-15) × 3-6 $\mu \mathrm{m}$, dark brown, usually located between host cells. Haustoria intracellular $2.5-3 \mu \mathrm{m}$ thick, threadlike, hyaline.

Specimens studied: FINLAND. Uusimaa. Helsinki, Degerö, on P. porelloides, 25.IX.1910 Huumonen (TUR, OULU). Etelä-Karjala. Miehikkälä, parish village, on P. asplenioides, 9.IX.1967 Fagerström (TUR, OULU). Pohjois-Savo. Kuopio, Neulamäki, on $P$. porelloides, 11.VI.1909 Huumonen (TUR, OULU).

Epicoccum Link. is a widespread, anamorphic hyphomycete, belonging to the family Pleosporaceae. Approximately 100 species have been described up to date (Kirk et al. 2008). E. plagiochilae is reported as new to Finland. It appears to be rare, though easy to identify when present.

\section{Lichenopeltella alpestris - Fig. 6, 13}

Ascomata superficial, (40-)50-70(-100) $\mu \mathrm{m}$ diam, 20-25 $\mu \mathrm{m}$ high, catathecioid, conical, dark brown, consisting of one layer. The lower cells are thin-walled, greyish, the upper are darkbrown, angular cells, 2-3 $\mu \mathrm{m}$ diam. Ostiole cir- cular, 5-8 $\mu \mathrm{m}$ diam, surrounded by thick-walled, dark-brown, up to $5 \mu \mathrm{m}$ high papillae, which from above look like hollow, rounded cells. Asci 30-35 × 10-13 $\mu \mathrm{m}$, eight-spored, bitunicate, fissitunicate in discharge, ellipsoid. Spores irregularly grouped in the ascus, $8.5-11 \times 2.5-3 \mu \mathrm{m}$, ellipsoid, hyaline, smooth, with a single median septum, not constricted at the septum, with four large oil droplets, with 1-3 very thin, medial appendages.

Selected specimens studied: FINLAND. VarsinaisSuomi. Länsi-Turunmaa, Parainen, on $P$. asplenioides, 20.VII.2004 Marsh (TUR). Raisio, Perno, on P. asplenioides, 18.VIII.1962 Laine (TUR). Turku, Halinen, on $P$. asplenioides, 29.VIII.2004 Marsh (TUR, two collections). RUSSIA. Sortavala District. Sortavala, Kirjavalahti, on P. porelloides, 13.VII.1927 Parvela (TUR, OULU).

The members of the genus Lichenopeltella Höhn. have charasteristic, catathecioid ascomata which resemble a shield. The majority of the species in the genus are lichenicolous, with the exception of a few bryicolous representatives and some species occurring on dying or dead vascular plants. Approximately 40 binomials have been reported in the genus (Kirk et al. 2008). No monograph has yet been prepared of the genus, although Aptroot et al. (1997) have presented a key for 26 species and Spooner \& Kirk (1990) for 10 British species.

The ascomata of this common species occur superficially on the leaves and stems of $P$. asplenioides and $P$. porelloides, with the majority of the findings on P. asplenioides. L. alpestris is the second most frequent fungus found on Plagiochila in Finnish material. The ascomata are typically situated on the ventral side of the leaf, quite close to the stem. Most frequently the ascomata can be found on the lower, dying, brown parts, but also on the upper, green parts of the host. They easily remain unobserved due to the tiny size and inconspicuous colouring. Only one observation of a Lichenopeltella growing on a hepatic has been made before. Lichenopeltella cetrariicola (Nyl.) R. Sant. has been reported from Lophozia barbata (Schmidel) Dumort. (Racovitza 1959), though its main host is the lichen Cetraria islandica (L.) Ach. Laukka (2005) has recorded L. palustris (J.P. Ellis) P.M. Kirk \& Minter on Sphagnum capillifolium (Ehrh.) Hedw. and S. magellanicum Brid. P. asplenioides and $P$. porelloides are here reported as new hosts to Lichenopeltella. 
The species was originally described from Carex leaves (Saccardo 1880). We follow Racovitza's (1959) interpretation that the species can also grow on bryophytes. Especially noteworthy are the roundish papillae around the ostiole, which can also be seen in Racovitza's plate. Free spores are illustrated as somewhat pointed, whereas those drawn inside the asci look identical to present material.

\section{Octosporella jungermanniarum - Fig. 4, 14}

Ascomata single, superficial, (250-)300-450($560) \times 200-400 \mu \mathrm{m}$ diam, ovoid to cylindrical, rounded at the apex and base, hairy, bright yellow to orange when dry, less colourful when rehydrated, white in old herbarium specimens. Ostiole circular, small, not easily seen. Hairs up to $200(-500) \mu \mathrm{m}$ long, $9-15 \mu \mathrm{m}$ wide at the base, tapering evenly to the apex, straight and stiff or bended and tangled, hyaline, thick-walled, rarely branched or septate. Asci 110-160 × (19-)21$27(-37) \mu \mathrm{m}$, usually eight-spored, unitunicate, narrowly ellipsoid, club- or clavate-shaped, rounded at the tip, MLZ-. Spores irregularly biseriate, $28-40(-48) \times(10-) 12-14(-16.5) \mu \mathrm{m}$, elongate ellipsoid, tapering towards the apex, hyaline, smooth, aseptate, with three large oil droplets, the middle one bigger than the others. Paraphyses 2-4 $\mu \mathrm{m}$ thick, ramifying, septate, yellowish, guttules inside. Hyphae 5-10 $\mu \mathrm{m}$ thick, hyaline, septate, forming an irregular, netlike structure on the surface of the host leaf. The hyphae give rise to lateral branches which consist of a stalk and a terminal appressorium. The shape of the stalk and appressorium resemble distinctly the neck and the head of a goose. Each appressorium produces a thread-like haustorium, which penetrates the host cell wall.

Specimens studied: FINLAND. Varsinais-Suomi. Salo, Suomusjärvi, on P. asplenioides, 9.IX.1954 Mäkinen (TUR). Etelä-Häme. Hämeenlinna, Vanaja, on $P$. asplenioides, 6.IX.1963 Hakulinen (two specimens, TUR, OULU). Jämsänkoski, Myllymäki, on P.asplenioides, 7.XI.2000 Eurola (TUR, OULU). Oulun Pohjanmaa. Pudasjärvi, Korpinen, on P. porelloides, 14.VI.2000 Ulvinen (TUR, OULU). Perä-Pohjanmaa. Rovaniemi, NE corner of Pisavaara Strict Nature Reserve, on P. asplenioides, 21.VIII.1989 Ulvinen (TUR, OULU).

The genus Octosporella Döbbeler consists of eight species obligately parasitic on hepatics, some of which were originally placed in the genera Nectria (Fr.) Fr. or Pseudonectria Seaver (Döbbeler 1980b), some being added subsequently. Characteristic features of the genus are perithecia-like ascomata and thin-walled, operculate asci, appressoria and intracellular haustoria. The modified shape of apothecia might be a response to xerophily. Yao et al. (2006) have compiled a key to the genus. Ascomata occur singularly and are often located inconspicuously on the ventral side of the host leaf. Octosporella jungermanniarum catches the eye when fresh with its bright orange colouring, whilst herbarium material loses its colour quickly. It is reported as new to Finland.

\section{Pleostigma jungermanniicola - Fig. 1, 15}

Ascomata superficial, singly or rarely two together, 90-215 $\mu \mathrm{m}$ diam, globose to ovate, glabrous. Ostiole circular, neck occasionally elongated. Excipulum pseudoparenchymatic, composed of 6-8 rows of isodiametric cells, with walls thickening towards the excipulum. Asci 75 $\times 30 \mu \mathrm{m}$, eight-spored, bitunicate, elongate to ellipsoid, very thick-walled and rounded at the tip. Spores biseriately or irregularly grouped in the ascus, (18-)20-27(-30) × (7-)10-11(-12) $\mu \mathrm{m}$, ellipsoid to elongated, brown to black, muriform, with 6-8 transverse and 1-2 longitudinal septa, not constricted. Hyphae superficial or under host cuticula, intracellular at the site of ascoma formation, 2.5-3 $\mu \mathrm{m}$ wide, septate, ramifying, hyaline to light brown.

Selected specimens studied: FINLAND. Etelä-Häme. Korpilahti, Oittila, on P. porelloides, 25.VI.1916 Siintola (TUR, OULU). Ruovesi, Visuvesi, on P. asplenioides, 23.VII.1948 Söyrinki (TUR, OULU). Ruovesi, Visuvesi, on P. asplenioides, 26.VIII.1946 Söyrinki (TUR, OULU). Oulun Pohjanmaa. Kiiminki, limestone area by the old Kuusamo road, on $P$. porelloides, 12.IX.1962 Ulvinen (TUR, OULU). Kiiminki, Murtoinsaaret, on P. asplenioides, 5.IX.1968 Ulvinen (TUR, OULU). Muhos, Muhosperä, on $P$. porelloides, 17.V.1962 Ohenoja 17a (TUR, OULU).

The genus Pleostigma Kirschst. accommodates nine species of ascomycetes with black, globose to semiglobose ascomata and muriform spores. These species occur on various substrates. The ascomata of $P$. jungermanniicola form in succession in every other leaf axil of $P$. asplenioides s.l. As the growth of the fungus follows the growth of the host liverwort, the ascomata form a 
zig-zag pattern on the stem, the size of the ascomata decreasing towards the apex of the host. On other hosts the perithecia may appear irregularly on the leaves or on the stem (Racovitza 1959). In addition to $P$. jungermanniicola, some other axil-dwelling, globose and glabrous ascomata have also been described from hosts belonging to Jungermanniales, including Pleosphaerella haploziae Racov., P. lophoziae Racov., and Pleospora hepaticola Walt. Watson. The ascomata of these related species also have a parenchymately built excipulum, bitunicate asci and brown, muriform spores. The reasons for this apparent similarity is still quite unclear. Both Döbbeler (1978, 2002) and Racovitza (1959) treated Pleospora hepaticola and Pleostigma jungermanniicola as different species, whereas Henderson (1972) proposed that $P$. hepaticola described by Watson (1914) is, in fact, $P$. jungermanniicola. These species are thought to be widespread and fairly common, but poorly studied (Döbbeler 1978). The scantiness of useful morphological characters of these minute organisms also accounts for the confusion.

Thirty records of $P$. jungermannicola were made from the regions of Varsinais-Suomi, Satakunta, Uusimaa, Pohjois-Karjala, EteläHäme, Pohjois-Häme, Oulun Pohjanmaa and Kainuu. Some of the known hosts are common and widespread in Finland, and probably would yield new records if examined.

\section{Abbreviated species descriptions for additional species known from $\boldsymbol{P}$. asplenioides s.l.}

\section{Belonioscyphella hypnorum}

Apothecia up to 700-(1000) $\mu \mathrm{m}$ high, (150-) 200-450(-600) $\mu \mathrm{m}$ diam, scattered, usually on the stem, hymenium flat, reddish when fresh, without hairs, stalk 75-150(-260) $\mu \mathrm{m}$ thick, often curved. Asci 140-210 × 14-19 $\mu \mathrm{m}$, unitunicate, thick-walled, clavate, 8 -spored. Spores $(27-) 33-40(-45) \times(6-) 7-8.5(-9.5) \mu \mathrm{m}$, elongate-ellipsoid, hyaline, with 3 (sometimes 4-6) septa, not strongly constricted, bipolarly asymmetric. Apical cells at the other or both ends of the ascospore produce phialide-bearing hyphae as they germinate. Phialides $6-10 \times 2.5-3 \mu \mathrm{m}$, phialospores single-celled, hyaline, ca. $2 \mu \mathrm{m}$ diam, widely ellipsoid. (Abbreviated from Döbbeler 1986a). Only once recorded on different mosses and P. asplenioides by Racovitza (1960).

\section{Bryorella erumpens}

Ascomata 50-75 $\mu \mathrm{m}$ diam, glabrous, slightly conical, lower part immersed in the substratum. Ostiole circular, 6-11 $\mu \mathrm{m}$ diam. Asci 26-34 $\times$ 7-8 $\mu \mathrm{m}$, bitunicate, from cylindrical to ellipsoid, eight-spored. Spores 9-11 × 3-3.5 $\mu \mathrm{m}$, ellipsoid, two-celled with one or two oil-bodies in each cell, hyaline, slightly constricted at septum. (Abbreviated from Döbbeler 1978).

\section{Epibryon endocarpum}

Ascomata solitarily within individual host leaf cells, (22-)25-35(-44) $\mu \mathrm{m}$ diam, 22-32(-40) $\mu \mathrm{m}$ high, perforating the host cell with an elongated, papilla-like neck. Ostiole 7-10 $\mu \mathrm{m}$ diam. Asci 11-15(-17) $\times$ 5-6 $\mu \mathrm{m}$, bitunicate, ellipsoid, eight-spored. Spores $7-8(-8.5) \times$ ca. $2 \mu \mathrm{m}$. twocelled, slightly or not constricted at septum. (Abbreviated from Döbbeler 1980a).

\section{Epibryon muscicola}

Ascomata 90-200 $\mu \mathrm{m} \times 55-145 \mu \mathrm{m}$ diam, pearshaped, superficial, brown. Ostiole $17-25,5 \mu \mathrm{m}$ in diam, protruding. Hairs 30-85 × 4-6 $\mu \mathrm{m}$, dark brown, septate. Asci 45-90 × 12-18 $\mu \mathrm{m}$, ellipsoid, eight-spored. Spores 12-28 × 6-8 $\mu \mathrm{m}$, ellipsoid, four-celled, hyaline, not constricted at septa. Hyphae 2-4.5 $\mu \mathrm{m}$ in diam, light brown, superficial and intracellular. (Abbreviated from Racovitza 1959).

\section{Nectria racovitzae}

Ascomata 180-320 $\mu \mathrm{m}$ diam, spherical, from pale to bright orange, superficially, singly or sparsely aggregated. Ostiole small, not visible. Hairs $70 \times 6(-10) \mu \mathrm{m}$, white, septate. Asci $60-85(-92) \times 11-16 \mu \mathrm{m}$, cylindrical to narrowly ellipsoid, eight-spored. Spores (22-)25-35(-40) $\times(5.5-) 6-7 \mu \mathrm{m}$, ellipsoid, two-celled, hyaline, slightly or not constricted, often with 2 large oilbodies in each cell. (Abbreviated from Döbbeler 1978). 

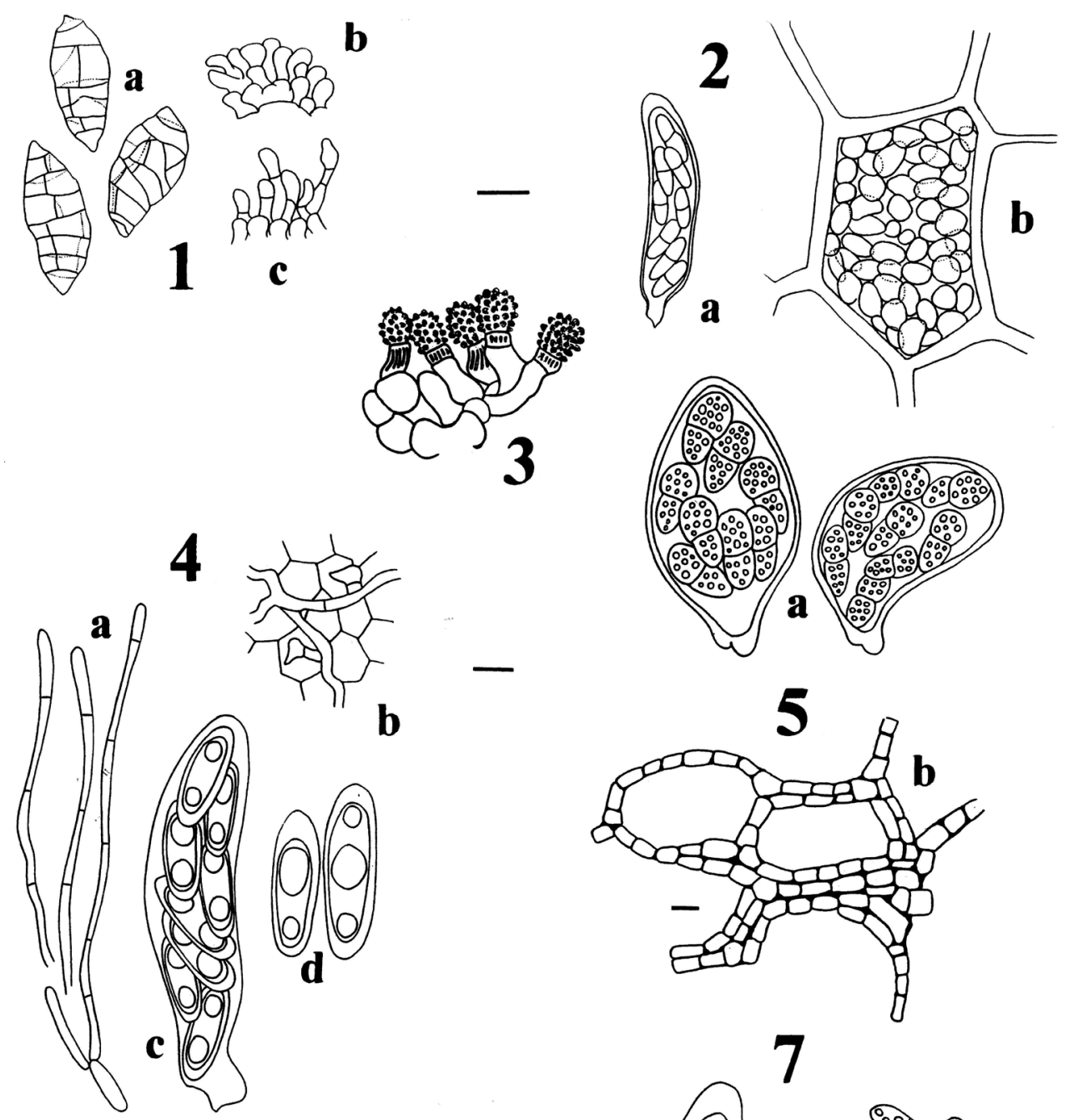

7
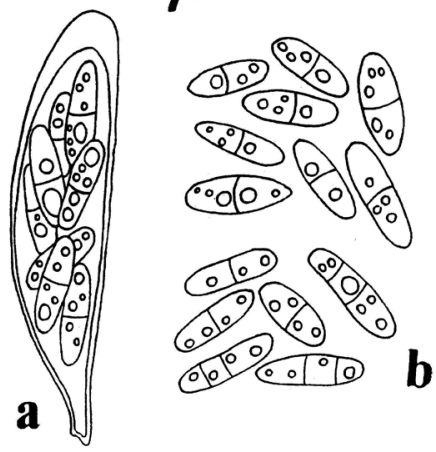

Figs. 1-7. Fungi on Plagiochila spp. 1) Pleostigma jungermanniicola $-\mathrm{a}=$ spores, $\mathrm{b}=$ excipulum, $\mathrm{c}=$ detail around ostiole. 2) Epibryon plagiochilae $-\mathrm{a}=$ ascus, $\mathrm{b}=$ host cell filled with mycelium. 3) Epicoccum plagiochilae conidiomata. 4) Octosporella jungermanniarum $-\mathrm{a}=$ paraphyses, $\mathrm{b}=$ hyphae with appressoria, $\mathrm{c}=$ immature ascus, $\mathrm{d}=$ mature spores. 5) Bryomyces hemisphaericus $-\mathrm{a}=$ mature asci, $\mathrm{b}=$ mycelium. 6) Lichenopeltella alpestris $-\mathrm{a}=$ spores, $\mathrm{b}=$ mature asci, $\mathrm{c}=$ ascoma. 7) Dactylospora heimerlii $-\mathrm{a}=$ mature ascus, $\mathrm{b}=$ spores, lower somewhat more rare. Scales $10 \mu \mathrm{m}$, for ascoma $20 \mu \mathrm{m}$. 

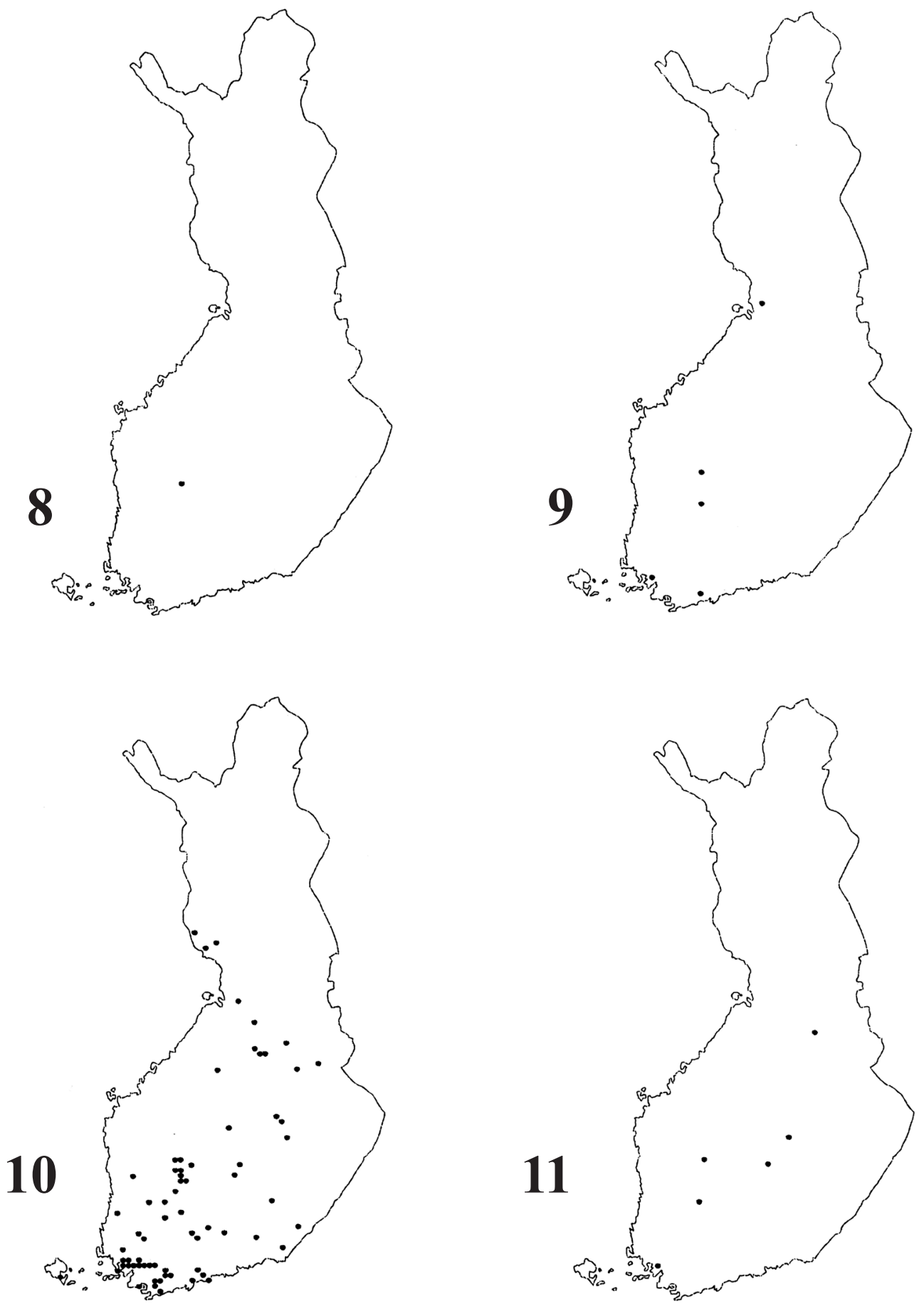

Figs 8-11. Distribution maps for fungi on Plagiochila spp. in Finland. 8) Bryomyces hemisphaericus. 9) Dactylospora heimerlii. 10) Epibryon plagiochilae. 11) Epibryon sp. 

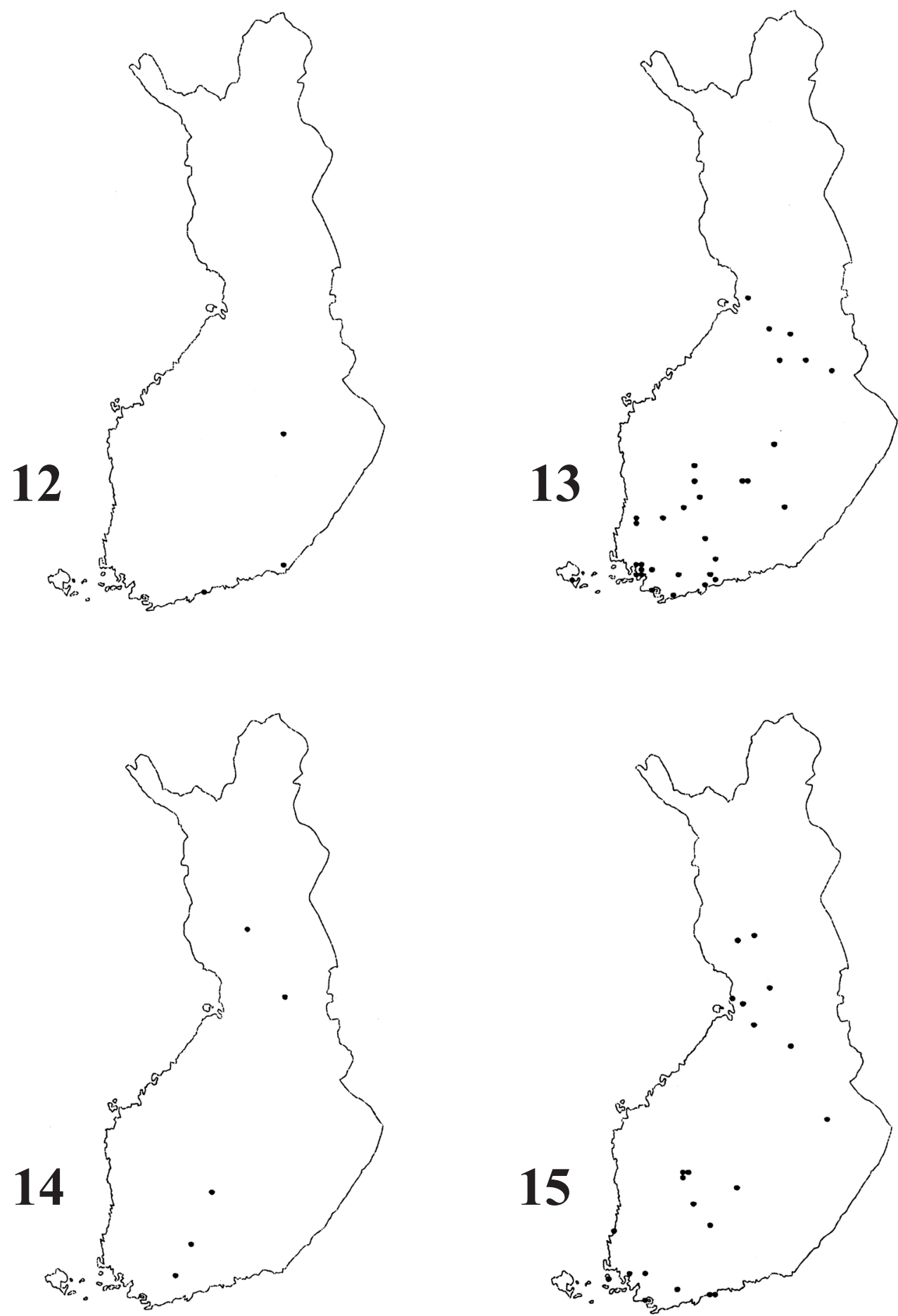

Figs 12-15. Distribution maps for fungi on Plagiochila spp. in Finland. 12) Epicoccum plagiochilae. 13) Lichenopeltella alpestris. 14) Octosporella jungermanniarum. 15) Pleostigma jungermanniicola. 


\section{Nectria salisburgensis}

Ascomata $85-115 \times 70-90 \mu \mathrm{m}$, densely covered by hairs, globose to pyriform, colourless, superficial. Ostiole inconspicuous. Hairs up to $40(-65) \times 1.5-2.5 \mu \mathrm{m}$, thick-walled. Asci 18-28 $\times 4-5 \mu \mathrm{m}$, cylindrical, eight-spored. Spores $(6-)$ $6.5-8.5 \times 1.5-2 \mu \mathrm{m}$, narrowly ellipsoid to rodshaped, two-celled, hyaline. Hyphae 1.5-3 $\mu \mathrm{m}$ diam, irregularly growing over and within the host cells. (Abbreviated from Döbbeler 1978). Nectria salisburgensis (syn. N. hirta) has been reported from decaying parts of $P$. porelloides. It is known only from the type collection.

\section{Phoma plagiochilae}

Pycnidia variable, (15-)20-45(-55) $\mu \mathrm{m}$ diam, glabrous, lower part immersed in host cell. Ostiole circular, 5(-6) $\mu \mathrm{m}$ diam, on the dorsal side of the leaf. Conidia elongate, hyaline, single-celled, $3.5-4.5(-5) \times$ ca. $1 \mu \mathrm{m}$. Hyphae variable, brown, 1.5-2.5 $\mu \mathrm{m}$ diam. (Abbreviated from Döbbeler 1981a).

\section{Discussion}

Bryicolous ascomycetes are especially rewarding for studies concentrating on a single substrate. Even a regionally restricted floristic approach, as presented here, is interesting to carry out, and most likely rewards the researcher with pleasant surprises, such as new records for the area or country, new host species, and even previously undescribed species.

The pros for choosing herbarium specimens as research material are that the material is abundant, easy to obtain and collected from a geographically large area. As the material studied shows, bryicolous ascomycetes can be found and identified even from material collected a hundred years ago. The cons are that the mosses collected in herbaria are likely to be biased towards healthy and vigorous individuals, whereas a person interested in collecting bryicolous ascomycetes should not overlook poorly growing or atypical moss or hepatic material. As Döbbeler (1997) points out, necrotrophic species of bryicolous ascomycetes are certainly underrepresented in bryological collections for the reason stated above.
There are two main reasons to assume that bryicolous fungi are much more common than records indicate. Firstly, we have observed that mosses and hepatics are virtually never free of hyphal infections, but as for most ascomycete species, the identification is based on the fertile structures, which may or may not be present. Secondly, the distribution of infections in cushions or mats of mosses and hepatics is patchy, and the selection of host plants collected for microscopic investigation must be done randomly, since most of bryicolous ascomycetes escape even the highest magnification of hand-lenses used in the field. It is obvious, that the vast majority of bryicolous ascomycetes still wait to be discovered and bryophytes remain as an Eldorado for mycologists.

Acknowledgements: This work was supported by the Ministry of the Environment, Finland, as a part of the research program of deficiently known and threatened forest species (PUTTE). The curator of the herbarium OULU is warmly thanked for the loans. Jouni Issakainen and Tomi Laukka are thanked for useful comments on the manuscript.

\section{References}

Aptroot, A., Diederich, P., Sérusiaux, E. \& Sipman, H.J.M. 1997: Lichens and lichenicolous fungi from New Guinea. - Bibliotheca Lichenologica 64: 83-99.

Bosanquet, S.D.S. 2007. Epibryon plagiochilae in south Wales: an overlooked British bryophilous fungus. Field Bryology 91: 24-25.

Corner, E.J.H. 1929: A humariaceous fungus parasitic on a liverwort. - Annals of Botany 43: 491-505.

Damsholt, K. 2002: Illustrated flora of Nordic liverworts and hornworts. -837 pp. Nordic Bryological Society, Lund.

Davey, M. \& Currah, R. 2006: Interactions between mosses (Bryophyta) and fungi. - Canadian Journal of Botany 84: 1509-1519.

Döbbeler, P. 1978: Moosbewohnende Ascomyceten I. Die pyrenocarpen, den Gametophyten besiedelnden Arten. - Mitteilungen der Botanischen Staatssammlung München 14: 1-360.

Döbbeler, P. 1980a: Epibryon endocarpum sp. nov. (Dothideales), ein hepaticoler Ascomycet mit intrazellulären Fruchtkörpern. - Zeitschrift für Mykologie 46: 209-216.

Döbbeler, P. 1980b: Moosbewohnende Ascomyceten IV. Zwei neue Arten der Gattung Octosporella (Pezizales). - Mitteilungen der Botanischen Staatssammlung München 16: 471-484. 
Döbbeler, P. 1981a: Phoma plagiochilae, ein interzellulärer lebermoosbewohnender Pyknidienbildner. - Mitteilungen der Botanischen Staatssammlung München 17: 231-236.

Döbbeler, P. 1981b: Moosbewohnende Ascomyceten V. Die auf Dawsonia vorkommenden Arten der Botanischen Staatssamlung München. - Mitteilungen der Botanischen Staatssammlung München 17: 393-473.

Döbbeler, P. 1986a: Belonioscyphella hypnorum (Helotiales, Ascomycetes), ein nekrotropher Parasit auf Laubmoosen. - Berichte der Bayerischen Botanischen Gesellschaft 57: 153-158.

Döbbeler, P. 1986b: Ein Zweitfund von Epicoccum plagiochilae (Hyphomycetes). - Mitteilungen der Botanischen Staatssammlung München 22: 485-492.

Döbbeler, P. 1997: Biodiversity of bryophilous ascomycetes. - Biodiversity and Conservation 6: 721-738.

Döbbeler, P. 1998: Ascomyceten auf der epiphyllen Radula flaccida (Hepaticae). - Nova Hedwigia 66: 325-373.

Döbbeler, P. 2002: Microniches occupied by bryophilous ascomycetes. - Nova Hedwigia 75: 275-306.

Döbbeler, P. 2003: Ascomycetes on Dendoligotrichum (Musci). - Nova Hedwigia 76: 1-44.

Döbbeler, P. 2006: Ascomycetes on Frullania dilatata (Hepaticae) from Tuscany. - Mycological Progress 5: 32-40.

Döbbeler, P. 2007: Ascomycetes on Polytrichadelphus aristatus (Musci). - Mycological Research 111: 14061421.

Döbbeler, P. \& Triebel, D. 1985. Hepaticole Vertreter der Gattungen Muellerella und Dactylospora (Ascomycetes). - Botanische Jahrbücher für Systematik 107: 503-519.

Felix, H. 1988: Fungi on bryophytes, a review. - Botanica Helvetica 98: 239-269.

Hafellener, J. 1979: Karschia. Revision einer Sammelgattung an der Grenze von lichenisierten und nichtlichenisierten Ascomyceten. - Beihefte, Nova Hedwigia 62: $1-248$.

Henderson, D.M. 1972: Fungi on Scottish bryophytes. Transactions of the Botanical Society of Edinburgh 41: $385-391$

Inoue, H. 1984: The genus Plagiochila (Dum.) Dum. in southeast Asia. -142 pp. +76 pl. Academic Scientific Book Inc., Tokyo.

Inoue, H. 1989: Plagiochila. - In: Geissler, P. \& Bischler, H. (eds.), Index hepaticarum 11, Naiadea to Pycnoscenus, pp. 106-273. Cramer, Berlin and Stuttgart.

Kirk, P.M., Cannon P.F., David J.C. \& Stalpers, J.A. 2008: Ainsworth and Bisby's dictionary of the fungi, $10^{\text {th }}$ Edition. - 771 pp. CAB International, Wallingford.

Laukka, T. 2005: Rahkasammalilla (Sphagnum) kasvavat mikroskooppiset kotelosienet Suomessa. - pp. 115 Licenciate thesis, University of Turku. [In Finnish].

Lesonen, A. 2006: Sirokorallisammalella (Ptilidium pulcherrinum) tavatut mikrosienet Suomessa. - pp. 61. Master's thesis, University of Turku. [In Finnish].

Marsh, T. 2005: Iso- ja pikkukastesammalen (Plagiochila asplenioides ssp. asplenioides ja ssp. porelloides) mikrosienilajisto Suomessa. - pp. 67. Master's thesis, University of Turku. [In Finnish].
Newton, M.E. 1986: Bryophyte phylogeny in terms of chromosome cytology. - Journal of Bryology, 14: 43-57.

Paton, J. A. 1999: The liverwort flora of the British Isles. - 626 pp. Harley Books, Colchester.

Racovitza, A. 1959: Étude systématique et biologique des champignons bryophiles. - Mémoires du Muséum National d'Histoire Naturelle, Sér B, Bot. 10: 1-288; pl. 1-84.

Racovitza, A. 1960: Contribuții la cunoaşterea ciupercilor briofile din R.P. Romînă. - Comunicarile Academiei Republicii Populare Romîne 10: 1111-1115.

Saccardo, P.A. 1880: Fungi Dalmatici pauci. - Michelia 2: $150-176$

Schofield, W.B. 1985: Introduction to bryology. - 431 pp. Macmillan Publishing Company, New York.

Schumacker, R. \& Váňa J. 2000: Identification keys to the liverworts and hornworts of Europe and Macaronesia (Distribution and status). - Documents de la Station Scientifique des Hautes-Fagnes 31: 1-160

Schuster, R.M. 1980: The Hepaticae and Anthocerotae of North America east of the hundredth meridian 4 . - 1334 pp. Columbia University Press, New York.

So, M.L. \& Grolle, R. 2000: Checklist of Plagiochila (Hepaticae) in Asia. - Journal of the Hattori Botanical Laboratory 88: 199-243.

Spooner, B.M. \& Kirk, P.M. 1990: Observations on some genera of Trichothyriaceae. - Mycological Reserach 94: 223-230.

Watson, W. 1914: Pleospora hepaticola sp. nov. - Transactions of the British Mycological Society 4: 295.

Yao, Y.-J., Spooner, B.M. \& Læssøe, T. 2006: Octosporella fusispora sp. nov. (Pezizales), with a key to the species of the genus. - Nova Hedwigia 82: 483-487. 